\title{
TAX REGULATION IN AGRICULTURE: CURRENT TRENDS, SELECTION OF A STATE SUPPORT FORMS
}

\begin{abstract}
In the article the problem of selection of state support forms for the agricultural sector is considered as one of the most important sectors of economics. Main purpose of the article is to determine the tax areas in Belarus taking into account international experience in taxation and subsidies of farmers, and processes of integration in the Eurasian Economic Union (EAEU). Agriculture with its sector particularity, social importance in solving problems of poverty, economic growth and food security is defined as a priority area of government funding. Main characteristics of tax incentives in developed countries were summarized based on national tax laws. It was concluded that, despite the preferential subsidies of the agricultural sector, tax regulators were widely used by different countries that allowed taking into account national particularity and priorities. Article reviewed current situation in the agricultural sector of the Republic of Belarus. Were studied directions of government financing of agriculture and peculiarities of its taxation. In the article were also generalized forms of tax exemptions for the producers of agricultural output. Were analyzed special tax regimes for agricultural organizations and peasant (farmer) households. Due to the active participation of the Republic in the integration entities were analyzed as well external factors, which influenced strategy of agricultural financing: commitments to reduce budget funds and taxes on farmers within the EAEU. Conclusions on need of reviewing mechanisms of national tax incentives were made, based on its effectiveness assessment and widening of the range of actions.
\end{abstract}

KEYWORDS. Tax regulation of the agricultural sector; unified tax on producers of agricultural output; taxation of peasant (farmer) households; tax exemptions; state support of agriculture.

FUNDING. This article was supported by the Belarusian Republican Foundation for Fundamental Research in the framework of the joint research project «BRFFR-RGNF 2015»: «Improvement of tax and budget instruments of a state financial support of agriculture in order to ensure economic and food security» (G15R-2015).

\author{
Е. Ф. Киреева \\ Белорусский государственный экономический университет, \\ г. Минск, Респубиика Беларусь
}

\section{НАЛОГОВОЕ РЕГУЛИРОВАНИЕ СЕАЬСКОГО ХОЗЯЙСТВА: СОВРЕМЕННЫЕ ТЕНАЕНЦИИ, ВЫБОР ФОРМ ГОСУААРСТВЕННОЙ ПОААЕРЖКИ}

\begin{abstract}
АННОтАЦИЯ. В статье исследуется проблема выбора форм государственной поддержки аграрного сектора как одного из наиболее значимых секторов экономики. Основная цель - определить направления налогообложения в Беларуси с учетом мирового опыта налогообложения и субсидирования сельхозпроизводителей, а также интеграционных процессов, происходящих в Евразийском экономическом союзе (ЕАЭС). Государственное финансирование сельского хозяйства, обладающего отраслевой спецификой и социальной значимостью в решении проблем бедности, экономического роста и продоволь-
\end{abstract}




\begin{abstract}
ственной безопасности, определено как приоритетное направление. На основе национальных налоговых законодательств обобщены особенности налогового стимулирования в развитых странах. Выявлено, что, несмотря на преимущественное субсидирование аграрного сектора, налоговые регуляторы активно применяются разными странами. Это позволяет учитывать национальную специфику и приоритеты. Кроме того, в исследовании рассматривается современное состояние сельского хозяйства Республики Беларусь, представлены направления его бюджетного финансирования и особенностей налогообложения, обобщаются виды налоговых льгот для производителей сельскохозяйственной продукции, анализируются специальные режимы налогообложения для сельскохозяйственных организаций и крестьянских (фермерских) хозяйств. В связи с активным участием республики в интеграционных образованиях изучаются внешние факторы, влияющие на стратегию финансирования сельского хозяйства: обязательства по сокращению бюджетных средств и налогообложение аграриев в рамках ЕАЭС. В результате были сделаны выводы о необходимости пересмотра механизмов национального налогового стимулирования на основе оценки их эффективности и расширения спектра действия.
\end{abstract}

КЛЮЧЕВЫЕ СЛОВА. Налоговое регулирование; аграрный сектор; единый налог; производители; сельскохозяйственная продукция; налогообложение; крестьянские (фермерские) хозяйства; налоговые льготы; государственная поддержка; сельское хозяйство.

ФИНАНСИРОВАНИЕ. Статья выполнена при финансовой поддержке Белорусского республиканского фонда фундаментальных исследований в рамках совместного научного проекта «БРФФИ-РГНФ 2015»: «Совершенствование налоговых и бюджетных инструментов государственной финансовой поддержки агропромышленного комплекса в целях обеспечения экономической и продовольственной безопасности» (Г15Р-2015).

\section{Introduction}

In the XXI century agricultural policy remains an essential instrument for achieving sustainable development and poverty reduction. In order agriculture has contributed to solving social and economic problems, it is necessary to improve the management in agriculture at the local, national and global levels ${ }^{1}$.

Financial support of agricultural production is a major factor in improving the competitiveness of the country. Long period of the return on investment, dependence on natural and climate conditions, rapid deterioration of agricultural funds, slow response of agricultural production to the conditions and requirements of the market are responsible for the low competitiveness of the sectors of agriculture and significantly reduce its investment attractiveness.

In order to stabilize agricultural production and improve the functioning of

1 OECD. Agricultural policies, Markets and Trade in OECD Countries: Monitoring and Evaluation, 2013. agricultural market it is used a system of direct and indirect levers of state financial support: budget subsidies and tax incentives. Complex of conducted performances should lead to an increase in investment activity in agricultural sector. At the same time creation of an attractive investment environment in the agricultural market contributes not only to the growth of gross domestic product, but also to reduction in unemployment, income and living standards increase in rural areas, growth of gross national income by an amount greater than the initial increase in investments, which is called «the effect of multiplier». As it noted in the report «Agriculture for Development» of the World Bank in 2008, the growth of gross domestic product (GDP) in agriculture is at least twice as effective in fighting poverty as growth in other sectors of the economics ${ }^{2}$. In this regard, well-built system of state financial support for agriculture, especially agricultural production, increases

2 URL: http://www.un.org/ru/development/surveys/docs/worlddev2008.pdf. 
incomes, and hence the level of the rural population $^{3}$.

Selection of a particular method of support depends on several factors (state of agriculture, geopolitical situation, competitiveness of produced outputs, existence and degree of the development of cooperation ties of participants), but primarily focuses on the purposes, which has a particular country $[1$, p. 6]. Significant impact on the use of financial instruments is provided by processes of integration and accession to the trade and integration unions. Commitments of the country to reduce direct subsidies to the agricultural sector and common approaches to coordinated agricultural policies encourage both agricultural producers and agricultural market as a whole to seek indirect methods of support, applying effective tax forms and mechanisms.

Tax support (tax exemptions granting) is a common management instrument to countries with developed and emerging economics. But the scale of this aid is much more modest in comparison with agricultural producers subsidizing due to the complexity of a specific recipient defining, additional tax administration, lack of methodologies for assessment of additional income earned from tax exemptions and others.

The problem also lies in the fact that one-time application of tax and budget instruments leads to the same result, because of their interchangeability. Thus such a use of tax and budget instruments to promote the development of the agricultural sector of economics can be seen on the one hand as inappropriate from the point of view of economy and losses for the state budget [2, p. 404].

On the other hand it allows having more comprehensive and flexible tools at the disposal of the state [3, p. 93]. That's why the issues of tax instruments improving to promote the development of the agricultural sector, focused on economic

${ }^{3}$ USDA Agricultural Projections to 2018. Office of Chief Economist, USDA, Interagency Agricultural Projection Committee, Long-Term Projections WAOB-2009-1, Washington D.C., United States, February, 2009. growth and competitiveness, are in the spotlight of the state, science and business.

\section{The degree of scrutiny and elaboration of the problem}

In the scientific community, issues of taxation in agriculture are widely highlighted. Many works of J. Becker, N. Stern, J. Buchanan, G. Tullock, M. Olson, B. Gardner and others are devoted to state regulation of the agricultural sector in developed countries.

Researches of agricultural taxation particularities in developing countries and countries with economics in transition could be found in E. Ahmad, K. R. X. Gordon, S. Rozelle. General issues of agricultural production taxation were considered by such scholars as L. Khorounzhiy, V. Panskov, M. Romanovsky, M. Shadrin and others.

Works on tax reforms and tax planning in the agricultural sector of American and European scientists were published in the last years, among them: J. M. Williamson (Agriculture, the Tax Code, and Potential Tax Reform), A. B Sharma (BRICS for end to rich nations' farm subsidies), S. Vogel (Farm Income and Costs: Farms Receiving Government Payments), etc. [4-6].

Belarusian scientists actively engaged in issues of pricing and financial support for agriculture: V. G. Gusakov, G. I. Ghanush, G. M. Lych, A. P. Shpak and others.

However, due to recurring changes in the economics as a whole, increasing threats in the global economics, and in the agricultural sector in particular, many theoretical and methodological issues require further study and practice requires better tools of financial support.

One of the most significant shortcomings of the current tax system is that it doesn't sufficiently stimulate the formation of development of the most important proportions in economics, and doesn't assist progressive structural changes in the agricultural sector, which could ensure its competitiveness.

Realizing the importance of conducted researches and the value of the results, it is necessary to note that the issues of agricultural sector taxation in conditions of 
integration processes deepening, ensuring of food security of the Belarusian economics require further reflection and development of new effective financial forms and instruments, corresponding trends of the world economic thought.

Recent years, Belarus has made serious steps, backed by legislative acts in the area of tax incentives of the subjects of agricultural activity and the creation of incentive funding mechanisms. Current legislation contains a number of provisions aimed at the use of tax incentives and preferential tax regimes.

In general, a current regulatory framework adequately defines the principles, purposes, directions and mechanisms of the agrarian policy of the state. At the same time in the country there is no scientifically-based strategy for the tax support of agricultural sector. Applicable tax incentive tools are not monitored, there is no methodology to assess their effectiveness, there is a need to further system based improvement of tax exemptions and financial leverages, comprehensive analysis of a tax policy in the conditions of formation of a unified economic space is required.

\section{Tax policy of developed countries in agriculture}

Agricultural sector because of its specificity is under special control of the state. Annually subsidies to this sector count billions of dollars. This is confirmed by the example of the European Union, where agricultural policy received considerable attention.

Despite the domestic subsidies and the allocation of funding from the EU funds, each state provides a number of measures stimulating agricultural production due to the nature of the production cycle, social significance, the aggravation of food risks, and other factors. Thus, agriculture in the global tax practice is seen as a specific object to which various tax exemptions and preferential regimes are applied. Moreover, this approach is almost universally used, along with the release of targeted subsidies and other budget mechanisms of state support for the agricultural sector [7, p. 12].

Generally in the structure of taxes paid by agriculture in developed countries, there are national taxes - corporate income tax, value added tax and local land, agricultural and others.

Agriculture, as a rule, has a preferential indirect taxation: VAT, sales tax.

There are different approaches to the establishment of VAT rates for farmers (for example, in a number of EU countries it depends on the level of the farmer's income), but mostly rates range depends on the type of product and its social and economic significance: reduced rates applied to agricultural and food products. Thus, the agricultural enterprises in Germany, France are fully exempted from $\mathrm{VAT}^{4}$. In China agricultural outputs, produced and implemented by farmers on their own are not taxed. In the US, in some states food is not subject to sales tax, or taxed at a reduced rate. Preferential regime for farmers is that when buying raw materials, plant and equipment for agriculture, this is not taxed.

Income corporate tax in most cases refers to national taxes, therefore, the order of payment and rates are set by fed-

4 The taxation of agriculture in the EU [Electronic resource]. URL: https://agrotypos. com/2016/01/27/the-taxation-of-agriculturein-the-eu.

Subsidies and taxes in the agricultural sector, 2010-2014 EU-28

\begin{tabular}{|l|r|r|r|r|r|}
\hline \multicolumn{1}{|c|}{ Indicators } & \multicolumn{1}{c|}{$\mathbf{2 0 1 0}$} & \multicolumn{1}{c|}{$\mathbf{2 0 1 1}$} & \multicolumn{1}{c|}{$\mathbf{2 0 1 2}$} & \multicolumn{1}{c|}{$\mathbf{2 0 1 3}$} & \multicolumn{1}{c|}{$\mathbf{2 0 1 4}$} \\
\hline Product subsidies less taxes, million EURO & 5497 & 4966 & 4200 & 3820 & 3300 \\
\hline Production subsidies less taxes, million EURO & 46096 & 48472 & 46705 & 47062 & 46831 \\
\hline $\begin{array}{l}\text { Subsidies less taxes as a share of value added at } \\
\text { producer prices, \% }\end{array}$ & 35,9 & 34,6 & 32,4 & 31,4 & 31,4 \\
\hline
\end{tabular}

Source: URL: http://ec.europa.eu/eurostat/statistics explained/index. php/File:Subsidies and taxes_in_the_agricultural_sector,_2010-14_YB15.png. 
eral legislation in all countries. Within the framework of direct taxation this tax applies different mechanisms and forms of incentives for the agricultural sector. The procedure of tax base reduce or tax exemption is widely applied.

For example, Australian milk producers on the hottest period - summer and early autumn - are exempted from paying certain taxes and pay for others in smaller amounts (overall decline of about $35 \%)$. Income less than 18200 thousand Australian dollars per year is not taxed, and the rate of income tax is reduced to $28,5 \%$ for companies with an annual taxable income less than 5 million Australian dollars. Also in India, individuals' income less than 200 thousand Indian rupee is not subject to income tax [8].

China has an exemption from corporate income tax (growing vegetables, cereals, oilseeds, pulses, sugar crops, fruits and nuts, breeding of new varieties of crops, livestock and poultry, as well as primary processing of products produced) and a $50 \%$ reduction of tax rate's basic of 12,5\% (growing flowers, tea and other plants, which are the materials for the manufacture of beverages and flavors, as well as primary processing of products produced). Peasants are exempted from agricultural tax, slaughter tax and tax on special agricultural products; in addition, all kinds of rural deductions were abolished: the accumulation fund, the social fund, and fund administration at the village level [8].

In France livestock cooperatives and consortia of cooperatives are exempt from corporate tax. In Italy, during the first 10 years since the establishment of agricultural cooperatives for the primary processing of agricultural products are exempt from paying tax on income of legal entities and local income tax.

In several countries of the southern EU (Spain, Portugal) and the former Eastern bloc (Poland, Romania, Hungary) there is a special preferential tax regimes for agricultural incomes. In addition, in some countries additional tax exemptions are applied for small farms and young farmers.
Poland is a country with the most favorable tax system for farmers in the EU. Farmers do not pay taxes on received agricultural income. Taxation provides only «rural tax» to their arable land. In 2015, its rate was about 3,4 euros per hectare.

In Romania and Hungary the lowest tax rate of $16 \%$ is applied for farmers.

Spain applies preferential tax treatment for farmers with an annual income from agriculture less than 250000 euros. It provides for the payment of VAT at the reduced rate, the fuel surcharge and the individual income tax. Also a reduced tax rate is applied for young farmers and producers with small farms ${ }^{5}$.

Some European countries apply to farmers a tax mechanism as a non-taxable income. So, Portugal exempts from tax the income from agriculture, which is less than 22600 euros. In Cyprus, the non-taxable income is 19500 euros. The United Kingdom has established a taxfree threshold of 10000 British pounds. The Netherlands - 4600 euros.

Germany offers a choice of income the general or the simplified system for small agricultural enterprises (not more than 200 acres of farmland, or 50 head of cattle). Tax-exempt income is 7664 euros.

In Sweden, the profit (income) of farmers is taxed at a reduced rate of $28,97 \%$, for young farmers it is reduced to $14,89 \%$ and for older farmers to $10,21 \%$.

The use of tax deductions system is also widely applied in practice of agricultural taxation. For example, in Germany, in addition to the deductions applicable to all citizens, there is a special deduction for individuals receiving income from agriculture and forestry. In Australia, individuals and legal entities, engaged in activities on land cultivation and animal husbandry have over 10 years the right to deduct the cost of telephone lines and ground clearance, to prevent the erosion of land costs in the year of expenditure.

5 URL: http://www.eurasiancommission. org/ru/act/prom i agroprom/dep agroprom/ sxs/Documents/Анализ \%20мировых\% 20тенденций \%20господдержки\%20cx.pdf. 
In Canada, when making investments that improve the quality of land, its value is subtracted from the taxed income of the farmer.

Accelerated procedure for depreciation of fixed assets. In agriculture, this procedure is stipulated in almost all countries. For example, in Australia they apply seven depreciation rates: $33,33 \%, 20 \%$, $15 \%, 10 \%, 7,5 \%, 5 \%, 2,5 \%$; tax authorities publish guidelines for the use of these rates, but the decision to use a particular rate is taken by the company itself. In India, the depreciation of the equipment is classified in three categories and amounts 25, 40 and $100 \%$.

Among other tools used for agricultural tax regulation can be emphasized an opportunity to change the tax period. In France, farmers with a certain level of income have a right to establish for themselves the production cycle, which does not coincide with the calendar year, and in the US they have the ability to pay tax once every three years (with the average income). In Canada - average income for the five-year period in order to protect farmers from sharp fluctuations in earnings inherent in the data sectors and in such a way to regulate the distribution of income by years for tax purposes.

In the majority of countries land tax is local. Methods of calculating land tax are different, but in general they are different types of a cadastral method. The tax rate for agricultural land is much lower than the tax rate for non-agricultural land (as a rule, does not exceed $1 \%$ of the value of the land). In land assessing it is taken into account its suitability for agriculture, relief, productiveness, availability of infrastructure.

Laws in many countries also use other methods of providing benefits for land tax:

- complete exclusion of agricultural land from taxation (for example, in the UK and China; melioration cooperatives in Italy, in Czech Republic up to 10 hectares, if it is handled by the owner);

- reduction of a tax rate (in Italy for agricultural cooperatives, located in mountainous areas, the land tax rate re- duced by 50 \%; in Czech Republic significant tax benefits can be provided to those areas of farmland, where the productivity is significantly lower than normal);

- an alternative to the payment of land tax. In some states of the USA there is an possibility to apply a reduced rate of income tax or a tax credit;

- exemption from the revaluation of land value (lands, where are made drainage, irrigation works, planting of fruit trees, in France, for example, temporarily are not revalueted).

Tax on sale of land plots shall be paid in a number of countries in addition to the land tax. As a basis for its calculation they use the actual sale price of the plot. In China they pay an additional agricultural tax, tax on agriculture (the use of arable land), on an increase of the land value (on a progressive scale from 30 to $60 \%$ ), tax on livestock (keeping and breeding of cattle).

The Australian Government in order to finance projects of grain research corporation has approved a special tax on farmers. Each year, the principal organization of the grain industry in Australia Australian grain producers (GPA) - sets its size: usually it is not more than $0,5 \%$ of the gross value of grain produced by farmers ${ }^{6}$.

Main parameters of the tax regulation of agriculture in developed countries show a significant number of similarities: tax policy in countries agriculture uses the entire arsenal of direct and indirect taxation, agricultural producers pay both federal and local taxes ${ }^{7}$. Hereby if the federal taxes in agricultural sector are unified, local taxes may vary considerably and are determined by the tasks of the region, its specific geographical and climatic situation, the national mentality.

6 URL: http://www.eurasiancommission. org/ru/act/prom_i_agroprom/dep_agroprom/ sxs/Documents/Анализ \% 20мировых \% 20тенденщий\%20господдержки\%20cx.pdf

7 Taxation trends in the European Union Data for the EU Member States, Iceland and Norway Statistical books [Electronic resource]. Luxembourg : Office of the European Union Publ., 2015. URL: http://ec.europa.eu/eurostat/ web/ess/-/taxation-trends-in-the-europeanunion-2015-edition. 


\section{The role of agriculture in the economy of the Republic of Belarus: current status and funding mechanisms}

The Belarusian economics, the agricultural sector has a significant share both in consumer market and in foreign trade. Agriculture provides economic growth and sufficient level of rural resident's income, solves food security issues, creates infrastructure in rural areas, and economic growth.

Today, the share of agriculture and forestry is about $6,7 \%$ of the GDP of the Republic of Belarus.

In 2015 the number of employed in the production of agricultural products amounted to about $8 \%(320,6$ thousand), the export of agricultural products and food products was $16,7 \%$.

The main share of the agricultural sector belongs to agricultural organizations. More than $70 \%$ of the agricultural organizations are entities of public or mixed (with the state share) ownership.

Dynamics of changes for each type of agricultural organizations represented in the figure 1.

There is a certain orientation of agricultural production. Large farms specialize in products that could be most effectively produced on a large scale and requires significant investments. The sector of private farms on small plots of land growing labor-intensive cultures. The share of small-scale private farms account for a small volume of gross agricultural output. Each type of farmers specialize in their key product groups. Crop pro- duction, which allows to receive the most benefits from the efficiency of scale (ie, corn, flax, sugar beet) and animal products, which require substantial investment in infrastructure and equipment (dairy cattle, breeding pigs and poultry), mainly belongs to large agricultural enterprises, while labor-intensive products, such as potatoes, vegetables and sheep (wool), are made by private farms.

The government is actively involved in managing of the sector, defining the production, ensuring the delivery of resources and the purchase of finished products, implementing or financing investments, adjusting prices and controlling wages. These structural constraints and government regulation inhibit private initiative, and (domestic and foreign) investment.

Analysis of key financial indicators for the last 4 years has shown unfavorable trend of faster growth in production costs to revenue and, as a consequence, income reduce of agricultural production.

More clearly, this trend - decline in profits and growth in a number of unprofitable agricultural enterprises can be traced in the figure 2 .

The number of unprofitable enterprises has increased 3,5 times over the past 4 years and amounted to 723 organizations, with the most negative trend developed in the agricultural organizations. While in 2012 there were only 56, in 2015 there were 503 organizations. Among the peasant (farmer) households, this trend doesn't have such a negative trend. In 2012, there were 125, in 2015 - 220 organizations.

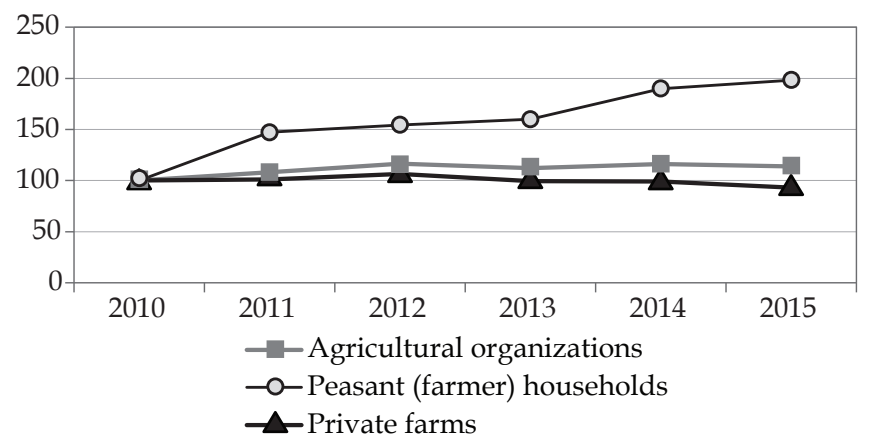

Figure 1. Dynamics of the number of agricultural enterprises by organizational forms for 2010-2015

Source: Agriculture in the Republic of Belarus: Stat. Sat. Mn., 2016. P. 17 


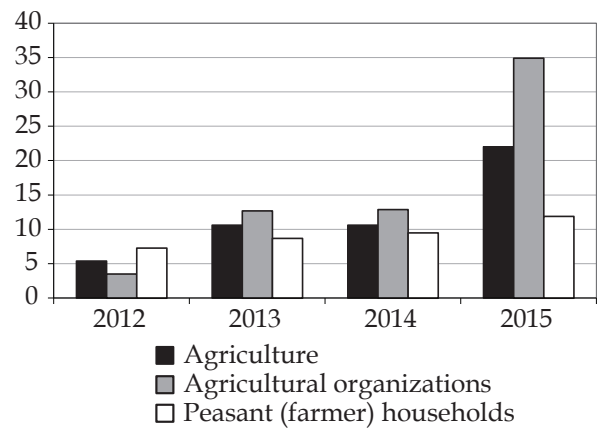

Figure 2. The share of unprofitable enterprises in the total number of organizations, interest

Source: Agriculture in the Republic

of Belarus: Stat. Sat. Mn., 2016. P. 174

In the table below we can see significantly deteriorated financial results (sum of the net loss, profitability of sold products, and returns on sales) during the analyzed period. Especially sharp drop in the last year under analysis (almost 11 times) was showed by the profitability of agricultural organizations. This shows once again a decrease in possible sources for payment of taxes.

The agricultural sector in the Republic of Belarus received substantial government support in the form of direct budget support, and through the use of various indirect levers.

The share of budget expenditures on agriculture in 2015 accounted for 7,3 \% of the total consolidated budget, which is more than in many other countries, al- though this figure dropped slightly in recent years.

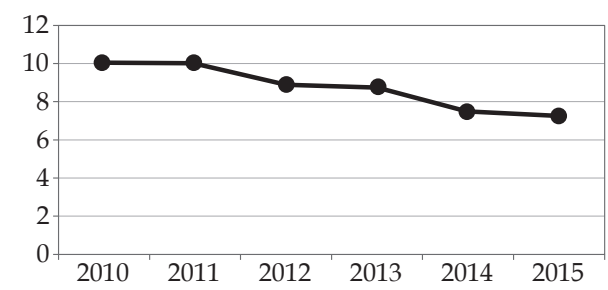

Figure 3. Expenses of the state budget for the financing of agriculture in $\mathbf{2 0 1 0 - 2 0 1 5}$

Source: Kireeva E. F. Tax regulation of the agricultural sector in Belarus: current state, the choice of forms of government support //

Innovative development ekonomiki. 2016. № 3 (33) II. S. 150

Main channels of budget allocations are as follows:

1. Funding of national activities: obligatory insurance, the formation of the state stabilization funds through purchasing and commodity interventions, the creation and development of social infrastructure, scientific conferences, etc.

2. Targeted funding entities directly engaged in agricultural production by subsidizing agricultural output, compensation of losses of agricultural producers in establishing the disparity in prices of industrial producers for goods (services) consumed by the agricultural sector, as well as providing individual state support in accordance with the law.

Financial performance of the agricultural organizations

Table 2 of the Republic of Belarus in 2010-2015

\begin{tabular}{|c|c|c|c|c|c|c|}
\hline Indicators & 2010 & 2011 & 2012 & 2013 & 2014 & 2015 \\
\hline \multicolumn{7}{|c|}{ The sum of the net loss of unprofitable organizations bn. rub. } \\
\hline Total: Agriculture & 77,3 & 104,1 & 159,9 & 478,5 & 923,8 & 734,3 \\
\hline Agricultural organizations & 76,4 & 97,4 & 151,1 & 462,0 & 902,0 & 687,6 \\
\hline Peasants (farmers) households & 0,9 & 6,6 & 8,9 & 16,5 & 21,7 & 46,7 \\
\hline \multicolumn{7}{|c|}{ Profitability of sold products, goods, works, services, \% } \\
\hline Total: Agriculture & 0,8 & 15,8 & 19,6 & 4,6 & 7,1 & 1,2 \\
\hline Agricultural organizations & 1,3 & 15,4 & 19,3 & 4,1 & 6,5 & 0,6 \\
\hline Peasants (farmers) households & 29,5 & 36,0 & 33,3 & 33,2 & 34,8 & 31,1 \\
\hline \multicolumn{7}{|c|}{ Return on sales, $\%$} \\
\hline Total: Agriculture & 0,7 & 12,3 & 14,7 & 3,9 & 5,9 & 1,1 \\
\hline Agricultural organizations & 1,2 & 12,0 & 14,6 & 3,5 & 5,5 & 0,5 \\
\hline Peasants (farmers) households & 20,5 & 24,7 & 22,7 & 22,7 & 23,5 & 21,8 \\
\hline
\end{tabular}

Source: Agriculture in the Republic of Belarus: Stat. Sat. Mn., 2016. S. 173-174. 
3. Compensate for the loss of commercial banks and the Development Bank of the Republic of Belarus in the issuance of loans to entities operating in the field of agriculture production on preferential basis.

Indirect measures of a state support are expressed primarily in the form of public procurement, price regulations and the application of tax exemptions or special tax regimes ${ }^{8}$.

\section{Tax exemptions and special regimes for farmers Belarus}

The main benefits in the field of agricultural production and processing of agricultural products in food are presented in Table 3.

While assessing the likely effect of the existing exemptions, it should be noted that the number of organizations to apply exemptions for income tax is not big. While in 2011 the number of taxpayers who have benefited, was 318 subjects, then a year later in 2015 it decreased by more

${ }^{8}$ URL: http://ec.europa.eu/eurostat/web/ ess /-/taxation-trends-in-the-european-union2015-edition. than a third (196 subjects) [8, p. 88]. This is primarily due to the low profitability and loss of agricultural production. The trend has developed for a number of reasons, among which there are objective - the general economic situation, the decline in sales in foreign markets, adverse weather conditions, as well as certain measures of state influence: price limits, low efficiency and productivity, including due to inefficient management.

Only 7 companies apply exemptions for land tax ( $0,5 \%$ of all taxpayers), and for real estate tax it is 254 organizations (16\% of all taxpayers). Total amount of benefits that stimulate agricultural production and processing of all the grounds in 2015 was - 398,1 billion rubles $(0,4 \%$ of total revenue) $[9$, c. 91; 10].

Thus, the conclusion was that existing system of granting tariff preferences of a general tax system for agriculture did not fully meet its function; it had a limited effect and insignificant volumes. This was one of the reasons for the abolition of exemptions for income tax for agricultural production from 2016.

\section{The main tax incentives for agricultural producers in Belarus}

Table 3

\begin{tabular}{|l|l|}
\hline \multicolumn{1}{|c|}{ Tax } & \multicolumn{1}{c|}{ Tax exemptions } \\
\hline $\begin{array}{l}\text { Cost-added tax - } \\
\text { base rate }-20 \%\end{array}$ & $\begin{array}{l}\text { It is applied a reduced rate of 10\%: } \\
\text { For plant products, wild products, beekeeping, animal husbandry (ex- } \\
\text { cept for fur production) and fish. Products must be made in the territory } \\
\text { of the Republic of Belarus and do not include agricultural products used } \\
\text { for decorative purposes. } \\
\text { Food products and products for children. The exemption granted on the } \\
\text { basis of a special list for produced or imported products }\end{array}$ \\
\hline $\begin{array}{l}\text { Corporate income } \\
\text { tax - base rate - } \\
18 \%\end{array}$ & $\begin{array}{l}\text { Tax exemptions: } \\
\text { Profit of organizations on sales - for plant products, wild products, } \\
\text { beekeeping, animal husbandry (except for fur production) and fish. } \\
\text { Products must be made in the territory of the Republic of Belarus and do } \\
\text { not include agricultural products used for decorative purposes. } \\
\text { Profit of organizations on sales of produced baby food }\end{array}$ \\
\hline Property tax & $\begin{array}{l}\text { Tax exemptions: } \\
\text { Buildings, facilities and other capital structures used for agricultural } \\
\text { production. } \\
\text { Buildings, facilities and other capital structures shopping destination } \\
\text { and catering consumer cooperatives, which are located in rural areas }\end{array}$ \\
\hline Land tax & $\begin{array}{l}\text { Tax exemptions: } \\
\text { Agricultural land, contaminated as a result of the Chernobyl disaster }\end{array}$ \\
\hline $\begin{array}{l}\text { Mandatory contribu- } \\
\text { tions to the FSNE }- \\
\text { base rate - 24 \% }\end{array}$ & $\begin{array}{l}\text { It is applied a reduced rate of 24 \%: } \\
\text { Employers engaged in the production of agricultural products (more } \\
\text { than 50\% of the total) }\end{array}$ \\
\hline
\end{tabular}

Source: compiled from the data of the Tax Code of Belarus (special part) of December 29, 2009. № 71-W / / (as amended from 30.12.2014g N 224-W). URL: www.ncpi.gov.by. 
Because of the importance and priority of the industry, many countries implement for agriculture or for its individual manufacturers special tax regimes. In Belarus, this mechanism is represented by introducing a special regime for agricultural producers - the unified tax for producers of agricultural products and the taxation of private (peasant) farms.

Organization, which proceeds from the sale of certain types of manufactured agricultural products is the total output of not less than $50 \%$ has the right to apply a unified tax.

Taxpayers are exempted from a number of tax payments: land tax and income tax, except for the profits from the sale of securities (shares) dividend. This form of taxation is, in fact, the use of turnover tax in the amount of $1 \%$ of revenue and a simplified form of accounting. Despite the fairly attractive conditions (at first sight) the number of payers of a unified tax is reduced.

What caused this? Special regime of the unified tax for producers of agricultural products actually replaces the payment of land tax and income tax.

Unified tax payers pay on general grounds: excise duties, VAT, taxes and general taxes, compulsory social payments, environmental taxes and recycling.

The exemption for income tax in accordance with the general tax legislation eliminates the advantages provided by a unified tax, and the amount of land tax is insignificant. Thus, applied tax regime has almost one advantage: the possibility of using a simplified accounting. To increase interest in moving to a unified state tax rate decreased in 2011 from $2 \%$ to $1 \%$. However, this did not change the trend of reducing the number of subjects using this tax regime. For the unified tax for producers of agricultural products on the background of nearly constant number of payers $(100,1 \%$ compared to 2014) the growth rate of tax was $95,4 \%$, which is directly linked to the reduction in revenue from sales of organizations operating in the field of agriculture.

If we evaluate the unified tax for agricultural producers in terms of the budget revenues, it also should be noted its insignificant value. According to the tax authorities the amount of the single tax for producers of agricultural products was $0,5-0,4 \%$ of total revenues for the period 2009-2015. Taking into account the above, we can make another conclusion, that the practice of imposing a special tax regime did not give positive results for any increase in the budget, nor to stimulate the development of the agricultural sector.

\section{Taxation of peasant (farmers) households}

Peasants (farmers) households are certain categories of taxpayers, for which the Tax Code of the Republic of Belarus establishes peculiarities of taxation. Virtually for them are set tax holidays.

These subjects within 3 years from the date of state registration are exempted from almost all taxes in the part of activities in production of agricultural crop production, animal husbandry, fish farming and beekeeping.

Peasants (farmers) households as a whole are entitled to refuse the features established by the Tax Code for this particular category of payers and go to the general taxation regime.

Hereby, when it refuses, household will be the payer of taxes in accordance with the established procedure: VAT, income tax and property tax (real estate, land and environmental).

If household abandons the use of imposed features of taxation, and it is considered as payer of all taxes, it can apply incentives for taxpayers who use the general taxation procedure (Fig. 4).

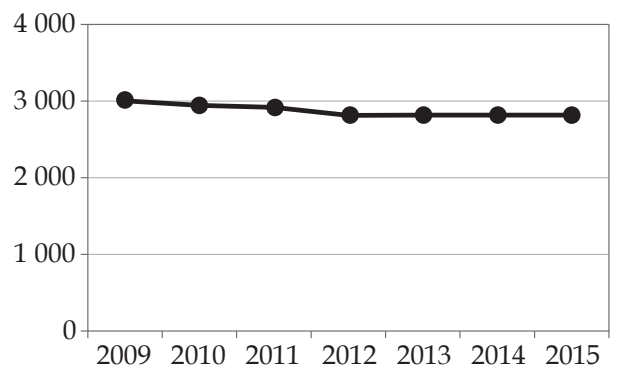

Figure 4. Dynamics of changes in the number of single taxpayers with agricultural producers for 2009-2015

Source: On the tax burden on the economy of the Republic of Belarus in 2015.

URL: http://www.nalog.gov.by/uploads/ documents/Nalog Nagr-MNS-2015.doc 
The number of these entities has grown steadily, while in 2011 the number was 2118 households, by 2015 already 2482 households. For many financial indicators peasants (farmers) have a more favorable trend: the number of loss-making among them is only 9,5\%; the profitability of sales - 34,8\% (in the agricultural organizations $-6,5 \%$ ); return on sales $-23,5 \%(-5,5 \%$ in the agricultural organizations) $)^{9}$.

This confirms the thesis that in the context of self-management and the provision of tax holidays for aligning the starting conditions, this form of organization of agricultural production is more efficient.

\section{Financial support for agriculture in the EAEU: mutual commitments and particularities of the national taxation}

The most important and fundamental issue of creating a common market of the EAEU and ensure equal competitive conditions are common approaches to the definition of state support for agriculture financing.

Given that common agricultural market is highly competitive, and the borders are open, the adverse effects on the supply of subsidized imports from one country are quite sharp and are subject to constant monitoring by interstate authorities.

Member States of EAEU can use without restrictions only state support measures, which doesn't have distorting effect on agricultural products trade between Member States [11].

These criteria are consistent with the criteria adopted by the WTO. Thus, it is expected that the measures are not distorting effects on trade these are measures of "green box» [12].

The authorized level of state support for agricultural is calculated as a percentage of the amount of state support for agriculture to the gross value of agricultural commodities produced in the whole and must not exceed 10 per cent. For the Republic of Belarus was set a transitional period until 2016 in order to minimize the

${ }^{9}$ URL: http://ec.europa.eu/eurostat/web/ ess/-/taxation-trends-in-the-european-union2015-edition. negative effects of reduced state support for the agricultural sector. During this period, the permitted amount of state support of agricultural measures should also be reduced to 10 percent.

Of the five Member States of EAEU four are members of WTO and in the framework of the EAEU in the Republic of Armenia, the Republic of Kazakhstan, the Kyrgyz Republic and the Russian Federation there are commitments, applied when joining WTO. In accordance with the terms of WTO membership for the Republic of Armenia commitments on the level of domestic support from 2008 are $5 \%$ of the gross value of agricultural output (the level of de minimis), before $2008-10 \%$. For the Republic of Kazakhstan - 8,5\%, for the Kyrgyz Republic - $5 \%$. Russia should reduce the maximum size from $\$ 9$ bln in 2012 to $\$ 4,4$ bln in $2018^{10}$.

Certainly, in these circumstances, the need to reduce budget subsidies to improve the efficiency of tax incentives for farmers are quite relevant. Moreover, the effectiveness of the applicable tax instruments should be seen not only in the national efficiency and competitiveness of local farmers in the common market.

Principles of taxation of agricultural producers in EAEU countries have a common basis, ie the level of tax burden for this category of economic agents is significantly lower than other sectors of the economy (through special preferential tax regimes or the use of tax incentives).

Comparative calculations carried out by the Eurasian Economic Commission, show that the tax burden on Belarusian agricultural producers per 1 ha of farmland is 3 and 10 times greater than that of the Russian and Kazakhstan, respective$1 y^{11}$. This once again confirms that there are a lot of possibilities of expanding the forms of tax incentives for farmers in the Belarusian tax system.

10 URL: http://www.eurasiancommission. org/ru/act/prom_i_agroprom/dep_agroprom/ monitoring/Documents/AНАЛИ3\% 20 общий\%20ЕАЭС.pdf.

11 URL: http://www.eurasiancommission. $\mathrm{org} / \mathrm{ru} / \mathrm{act} / \mathrm{prom}$ i agroprom/dep agroprom/ monitoring/Documents/AНАЛИ3\% 20 общий\%20ЕАЭС.pdf. 
The types and rates of main taxes in the Member States EAEC in 2015, \%

Table 4

\begin{tabular}{|c|c|c|c|c|c|}
\hline Type of tax & $\begin{array}{l}\text { Republic } \\
\text { of Armenia }\end{array}$ & $\begin{array}{l}\text { Republic } \\
\text { of Belarus }\end{array}$ & $\begin{array}{c}\text { Republic } \\
\text { of Kazakhstan }\end{array}$ & $\begin{array}{c}\text { The Kyrgyz } \\
\text { Republic }\end{array}$ & $\begin{array}{c}\text { Russian } \\
\text { Federation }\end{array}$ \\
\hline $\begin{array}{l}\text { Unified tax for producers } \\
\text { of agricultural outputs }\end{array}$ & - & $1^{2}$ & - & - & $6^{3}$ \\
\hline Unified land tax & - & - & $0,5^{1}$ & - & - \\
\hline $\begin{array}{l}\text { Land tax: } \\
\text { For legal entities }\end{array}$ & $15^{5}$ & - & - & $20^{6}$ & - \\
\hline For agricultural producers & 0 & - & - & 0 & - \\
\hline $\begin{array}{l}\text { Value added tax: } \\
\text { For legal entities }\end{array}$ & 20 & 20 & $\begin{array}{c}\text { Corporate tax } \\
12 \\
\end{array}$ & $12^{7}$ & 18 \\
\hline For agricultural producers 4 & - & 10 & 12 & - & 10 \\
\hline $\begin{array}{l}\text { Profit tax: } \\
\text { For legal entities }\end{array}$ & 20 & 18 & 20 & 10 & - \\
\hline For agricultural producers 4 & - & - & 10 & - & 20 \\
\hline Tax on individual income & From $24,4^{8}$ & 13 & 11 & 10 & 13 \\
\hline $\begin{array}{l}\text { Social tax: } \\
\text { For legal entities }\end{array}$ & - & 28 & 11 & - & 34 \\
\hline For agricultural producers ${ }^{4}$ & - & 24 & - & - & - \\
\hline Tax on sales (Individuals) & Not set & - & - & $\begin{array}{c}1 \text { (2 For ser- } \\
\text { vices })\end{array}$ & - \\
\hline Property Tax & $\begin{array}{l}0,3-\text { of } \\
\text { the tax } \\
\text { base for } \\
\text { public } \\
\text { build- } \\
\text { ings and } \\
\text { industrial } \\
\text { differents }\end{array}$ & $\begin{array}{l}\text { Differ- } \\
\text { entiated } \\
\text { rate } \\
0,1-2\end{array}$ & $\begin{array}{c}\text { Differentiated } \\
\text { rate } 0,05-1,5\end{array}$ & $\begin{array}{l}0,35-\text { for } \\
\text { residential } \\
\text { buildings; } \\
0,8-\text { for } \\
\text { property used } \\
\text { for economic } \\
\text { activities; } \\
0,3-\text { industry } \\
\text { coefficient for } \\
\text { agricultural } \\
\text { production } \\
\text { buildings }\end{array}$ & $\begin{array}{l}\text { Differenti- } \\
\text { ated rate } \\
\leq 2,2\end{array}$ \\
\hline
\end{tabular}

Note: 1 - the basis for calculating land tax is the land area multiplied by the estimated value; 2 subject to taxation at a unified tax is the gross revenue from the sale of goods; ${ }^{3}-$ subject to taxation at a unified tax is the net proceeds from the sale of goods; 4 - for employers engaged in agricultural production, which amounts to over $50 \%$ of total production; 5 - subject to taxation for agricultural lands is net income, determined by a cadastral estimation of the land; 6 - the basis for calculating land tax is the area of land specified in the certifying documents, the base rate for land tax is charged at a separate scale for irrigated land and rainfed for $1 \mathrm{~g} ; 7$ - the rate calculated net income determined by the cadastral value; 8 - the main supply of agricultural products of own production are exempt from VAT.

Source: Analysis of the existing agri-food market regulation systems in the Member States of the EAEC in taxation, credit, insurance, price regulation and licensing system. URL: http://www.eurasiancommission.org/ru/act/prom_i_agroprom/dep_agroprom/monitoring/Documents/ANALIZ\%20 obschiy\%20EAES.pdf.

\section{Conclusions}

International experience demonstrates the priority for funding agriculture, due to the peculiarities of industrial production, social significance in solving the problems of poverty, economic growth and food security, which is defined as a priority area of public funding.
In this regard, many countries are reviewing their agricultural policies and return to the issue of increasing domestic production to meet the needs of their countries in the food and creating or increasing public stocks. This in turn leads to significant costs for the economics in the form of direct transfers, ie budget ex- 
penditures for such activities, and / or as a diversion of productive resources by the most effective sectors.

As one of the alternatives to direct subsidies, which has no substitute, but complementary effect and are focused more on stimulating influence of certain groups of producers (farmers and other small forms, youth), serving industry with high innovation effect (new technologies in the production of agricultural machinery and equipment, feedstuffs, biological products, breeding), and others is the tax policy.

The Republic of Belarus has a developed agricultural sector, high export and internal potential that provide food security. The system of state regulation and budget support for agriculture in the country played an important role in improving the performance of the agricultural sector. At the same time, the emergence of internal and external threats that led to a deterioration in the financial condition of the agricultural sector, a narrowing of the market, lack of occupancy of the budget do not allow for the existing high level of budget financing of expenses to support the agricultural sector. Serious pressures have also com- mitments to reduce financial support for agriculture within the EAEU. Subsidies for export-oriented sectors of agriculture provide competitiveness of Belarusian products, but is practically subsidizing of the importing country.

Analysis of the existing rules of the national tax legislation and taxation of agricultural producers on the general market of EAEU showed less attractive tax conditions for Belarusian farmers and, as a consequence, loss of competitiveness due to this factor. Applied in Belarus tax incentives for agriculture do not bring the desired effect for its development and do not represent the values of the fiscal budget.

What to choose? State subsidies or tax incentives? The answer lies in a different plane, not by any means, but for what purposes. In order to stabilize and improve the functioning of the agricultural market is necessary to reorient the system of financing on the growth of investment activity in the agricultural sector. First of all, support should be oriented on the most efficient farms producing competitive products. The tax system also requires a review to assess the effectiveness of tax incentives, to stimulate small businesses and innovative projects.

\section{References}

1. Heady D., M. Alauddin, D. S. Prasada Rao. Explaining agricultural productivity growth: an international perspective. Agricultural Economics, 2010, vol. 41 (1), pp. 1-14.

2. Rausser G. C., Chalfant J. A., Love H. A., Stamoulis K. G. Macroeconomic linkages, taxes, and subsidies in the U.S. agricultural sector. American Journal of Agricultural Economics, Agricultural and Applied Economics Association, 1986, vol. 68 (2), pp. 399-412.

3. Bird R. M. Taxing Agricultural Land in Developing Countries. Cambridge, MA, Harvard University Press, 1074. 144 p.

4. Williamson J. M. Agriculture, the tax code, and potential tax reform. American Journal of Agricultural economics, 2013, Vol. 28, iss. 2, pp. 12-16.

5. Sharma A. B. BRICS for end to rich nations' farm subsidies. The Indian Awaaz, 2012. Available at: http:// theindianawaaz.com.

6. Vogel S. Farm Income and Costs: Farms Receiving Government Payments. Available at: http://www.ers.usda.gov/topics/farm-economy/farm-sector-income-finances.aspx.

7. Veen H. B., van der, Meulen H. A. B., van der, Bommel K. H. M., Doorneweert B. Exploring Agricultural Taxation in Europe. Hague, LEI, 2007. 162 p.

8. Moiseeva L. A. Taxation of agriculture in foreign countries. Koncept, 2015, vol. 13, pp. 221-225. Available at: http://e-koncept.ru/2015/85045.htm. (In Russian).

9. Kireeva E. F. Tax regulation of the agricultural sector in Belarus: current state and selection the forms of the state support. Innovatsionnoe razvitie ekonomiki = Innovative development of economy, 2016, no. 3-2 (33), pp. 149-153. (In Russian).

10. Kireeva E. F., Luk'yanova I. A. National tax system: trends and prospects of modernization. Belorusskii ekonomicheskii zhurnal = Belarusian Economic Journal, 2015, no. 3. pp. 84-97. (In Russian). 
11. Lerman Z., Sedik D. Agricultural Cooperatives in Eurasia. Budapest, FAO Regional Office for Europe and Central Asia Publ., 2014. 19 p. Series: Policy Studies on Rural Transition, no. 2014-3.

12. Legg W. Agricultural Subsidies: Measurement and Use in Policy Evaluation. Journal of Agricultural Economics, 2003, no. 54, iss. 2, pp. 175-200.

\section{Author}

Elena F. Kireyeva - Doctor of Economics, Professor, Head of the Taxes and Taxation Department, Belarus State Economic University, Minsk, Belarus (26 Partizanskiy prosp., 220070, Minsk, Belarus); e-mail: kireeva-e@yandex.ru.

\section{Информация об авторе}

Киреева Елена Федоровна - доктор экономических наук, профессор, заведующий кафедрой налогов и налогообложения, Белорусский государственный экономический университет, г. Минск, Республика Беларусь (220070, г. Минск, просп. Партизанский, 26); e-mail: kireeva-e@yandex.ru. 